\title{
Development of molecularly imprinted polymer membranes with specificity to triazine herbicides, prepared by the «surface photografting» technique
}

\author{
T. A. Sergeyeva ${ }^{1}$, H. Matuschewski ${ }^{2}$, S. A. Piletsky ${ }^{1,3}$, U. Schedler ${ }^{2}$, M. Ulbricht ${ }^{4}$ \\ 1 Institute of Molecular Biology and Genetics National Academy of Sciences of Ukraine \\ 150 vul. Acad. Zabolotnoho, Kyiv, 03143, Ukraine \\ 2 \\ Poly-An GmbH \\ Rudolf-Baschant-Str. 2, 13086 Beriin, Germany \\ ${ }^{3}$ Institute of Bioscience and Technology, Cranfield University at Silsoe \\ Bedfordshire, MK45 4 DT, UK \\ niversitat Duisburg-Essen \\ Universitat-Str. 5, 45117 Essen, Germany \\ E-mail: t_sergeyeva@yahoo.co.uk
}

\begin{abstract}
"Surface photografting» of polypropylene (PPy) microporous membranes by molecularly imprinted polymers selective to triazine herbicides has been carried out by the UV irradiation-initiated copolymerization of the functional monomer (2-acrylamido-2-methyl-1-propane sulphonic acid) and a cross-linker ( $N, N^{\prime}$-methylene-bis-acrylamide) in the presence of the template (terbumeton) onto photoinitiator (benzophenone)-coated samples. The grafting reaction occurs in a thin liquid layer on the membrane substrate, which is pre-soaked in a dimethyl formamide solution containing template, functional monomer and cross-linker. After irradiation with a $500 \mathrm{~W}$ mercury lamp for $10 \mathrm{~min}$ at room temperature, the membranes covered with the layer of imprinted polymer were obtained. The recognition sites complementary to terbumeton were formed in the membranes after extraction of the template molecules with methanol. Alternatively, reference polymeric membranes were prepared with the same monomer composition, but without the template. The membranes' recognition properties were estimated by their capability to herbicide adsorption from its aqueous solution. The membranes modified by the mixture of monomers containing terbumeton showed significantly higher adsorption capability to this herbicide than to analogous compounds (terbuthylazine, atrazine, desmetryn, metribuzine). The effect of the polymer composition on the binding properties of the membranes has been investigated. High affinity of these membranes to triazine herbicides together with their inexpensive preparation, provide a good basis for applications of molecularly imprinted polymer membranes in separation and solid-phase extraction.
\end{abstract}

Introduction. In many applications of bioorganic and environmental chemistry it is desirable to utilize a membrane filter, which is mechanically strong, thermally stable, insoluble in most organic solvents, relatively inert chemically and has affinity to certain analyte $[1-3]$. The binding properties of affinity membranes are determined by specific receptor-ligand interactions. However, synthesis of the membranes selective for a broad range of neutral molecules is challenged by the difficulty of incorporating specific

(C) $r$. A. SERCIEYEYA, H. MATUSCHEWSKI, $S$ A PIIETSKY, U. SCHEDLER, M. ULBRICHT, 2004 receptors for such molecules. Therefore, the development of synthetic membranes, which possess the selectivity of natural receptors and stability of synthetic polymers in harsh environments, is of great importance. Recently, a considerable attention has been paid to the development of molecular imprinting technique, which allows one to obtain synthetic polymers mimicking biological receptors $[4-6]$. According to this approach, highly cross-linked polymers are formed around a template molecule. The template is then removed leaving cavities capable of binding template molecules back. As widely recognized, mo- 
lecularly imprinted polymers (MIPs) can provide high selectivity to low-molecular weight compounds [7-8], very good thermal and mechanical stability [9], their production is inexpensive.

Polymers of this type have been used as stationary-phase materials to make highly selective liquid chromatography columns $[10]$, as substitutes for antibodies in competitive binding assays [11-13], and as selective elements of chemical sensors [14]. Chromatographic and SPE applications traditionally utilize MIP particles prepared by grinding and sieving of synthesized polymer blocks or the particles prepared by suspension polymerization. The first approach is time consuming, may lead to the destruction of some binding sites in the polymer and produces a relatively low yield of the fraction with a narrow size distribution. In the second approach, the choice of monomers is limited to those, which are not soluble in the dispersion phase. Additionally the synthesized beads are not always uniform in their shape and size. Thus, again a sieving procedure is required which makes column packing time-consuming, expensive and ineffective. Use of polymer particles of a small size in chromatography is also associated with too high backpressure. Therefore, the method of molecular imprinting was also combined with the membrane technology in order to develop new generation of stable affinity membranes for the separation of the target molecules from a mixture of structurally similar compounds $[15-17]$. However, the high selectivity and stability of these membranes were shaded by their ineffective performance, particularly due to small fluxes. Typically, the fluxes observed were not larger than $10^{-4} \mathrm{~mol} \cdot \mathrm{m}^{-2} \cdot \mathrm{h}^{-1}$ [18]. This effect can be related to the high degrees of cross-linking of MIPs, which is a prerequisite for the imprinted membranes selectivity.

Other approaches to the synthesis of affinity membranes are chemical or the photografting of a thin layer of the imprinted polymer to the surface of a porous membrane. There have been two recent reports on the polymers [19] and membranes [20] grafted with MIPs. In the last case the laboratorymade membranes from photo-reactive polymer (polyacrylonitrile-co-diethylaminodithiocarbamoyl methylstyrene) were grafted with acrylic acid and $\mathrm{N}, \mathrm{N}^{\prime}-$ methylene-bis-acrylamide in the presence of theophylline yielding theophylline-specific membranes. Unfortunately, the use of a special polymer for the membranes formation together with long reaction times for MIP functionalization $(24 \mathrm{~h})$ substantially reduce the areas of the membranes' applications. Much more efficient method for the membrane surface functionalization is currently being explored [21].
The aim of the present research is the development of a general method for molecular imprinting the surface of a stable synthetic polymer membrane. Surface photograft co-polymerization in the presence of a template should introduce specific binding sites into the porous membrane without damaging its pore structure and, thus, preserving its transport properties.

The present paper describes the procedure of modification of commercially available microporous membranes with a herbicide-imprinted polymer using technique of «surface photografting» from organic solvents. This substantially broadens the number of potential templates allowing one to use a wide range of substances poorly soluble in aqueous environment. The membranes modified with the imprinted polymers possess high selectivity to the analyte without significant change in their original permeability.

Materials and Methods. Polypropylene (PPy) and polyamide (PA) membranes (Accurel PP 2E HF, nominal pore size $\mathrm{dp}=0.2 \mu \mathrm{m}$; membrane thickness $\mathrm{dm}=150 \mu \mathrm{m}$ ) were purchased from Akzo Nobel. Acrylic acid (AA), methacrylic acid (MA) and 2acrylamido-2-methyl-1-propane sulphonic acid (AMPS) were obtained from «Aldrich» (USA), benzophenone (BP) and $\mathrm{N}, \mathrm{N}^{\prime}$-methylene-bis-acrylamide were purchased from «Merck» (Germany). Terbumeton, desmetryn, terbutylazin (NMR, HPLC grade) were obtained from «Sigma» (USA). All other chemicals and solvents (HPLC grade) were obtained from the commercial sources and used as received without further purification.

Preparation of membranes modified by molecularly imprinted polymers. Circular PPy or PA membrane samples $\left(A=5 \mathrm{~cm}^{2}\right)$ were extracted with chloroform in Soxhlet apparatus during $4 \mathrm{~h}$, dried and weighted. The membranes were then pre-soaked in $0.15 \mathrm{M}$ solution of $\mathrm{BP}$ in acetone for $5 \mathrm{~min}$ and dried under vacuum. The pre-coated with photoinitiator membranes were transferred to a dimethyl formamide (DMF) solution, containing $10 \mathrm{mM}$ of terbumeton, $50 \mathrm{mM}$ of functional monomer (acrylic, methacrylic or 2-acrylamido-2-methyl-1-propane sulphonic acid), $150-500 \mathrm{mM}$ of $\mathrm{N}, \mathrm{N}^{\prime}$-methylene-bis-acrylamide. To prevent desorption of the photoinitiator from previously coated membranes $5 \mathrm{mM}$ of $\mathrm{BP}$ was added to the monomer mixture. The pre-soaked for $5 \mathrm{~min}$ in the monomer mixture membranes were then UV irradiated on a pilot-scale UV curing system $(500 \mathrm{~W}$ mercury lamp; Beltron $\mathrm{GmbH}$, Germany) for 10 cycles $(1$ cycle $=1 \mathrm{~min})$. To remove the homopolymer, residual chemicals and template, the resulting membranes were extracted by hot methanol in Soxhlet apparatus for 2 hours. After drying the membranes 


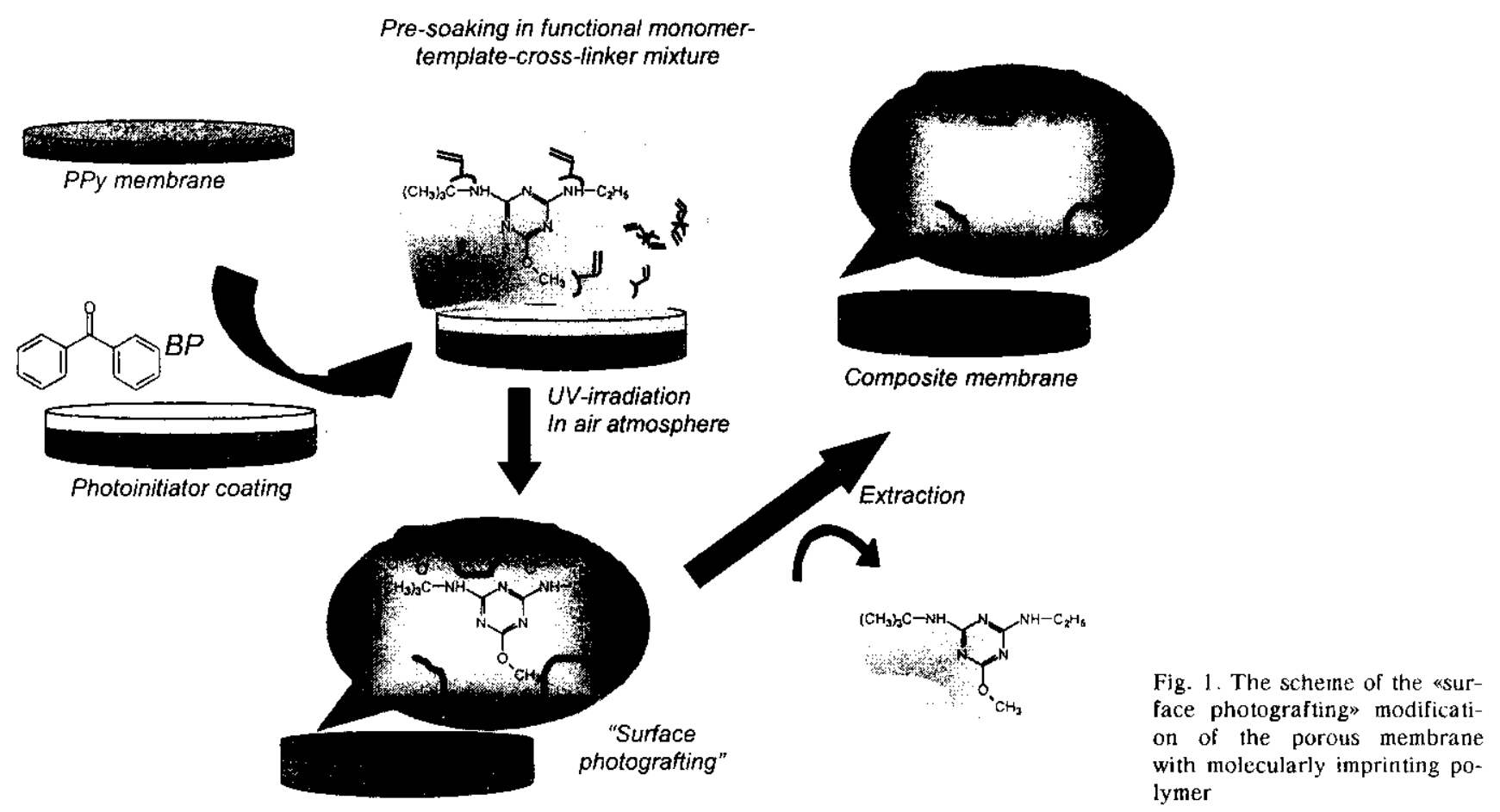

were weighted again and the degree of modification (DM) was calculated from weight differences.

Membranes' characterization. The binding properties of the membranes were estimated by their capability to herbicide adsorption from its aqeous solution. Adsorption of the herbicide from water by the membrane was estimated in filtration experiments using syringe connected to a filtration cell holder $(\mathrm{d}=$ $=25 \mathrm{~mm}$, «Schleicher \& Schull», Germany). In the adsorption experiments $10 \mathrm{ml}$ of $5 \cdot 10^{-7}-10^{-4} \mathrm{M}$ herbicide solution were filtered through the membranes, typically at a rate of $10 \mathrm{ml} / \mathrm{min}$. The filtrate was extracted with $10 \mathrm{ml}$ of chloroform. The herbicide concentrations in both feed and permeate solutions were determined by gas chromatography after the extraction procedure using Hewlet Packard GC system HP 6890 with the mass selective detector HP 5973 (column HP5MS).

Results and Discussion. During the last decades, within the field of surface modification of various substrates, photografting from organic solvents has received wide attention $[22-25]$. In general, such technique has involved immersion of the substrate to be grafted in a solution of monomer in an organic solvent, and subsequent exposure to irtadiation. Such photo-induced grafting is accompanied by extensive homopolymerization and often causes uneven modification of the substrate surface. Recently Ranby et al. have proposed a new method of «surface photo- grafting» for polymer modification, where the substrate is pre-soaked in a solution of monomer and then UV-irradiated in an inert atmosphere [26]. According to this technique, the grafting reaction occurs in a thin layer of the solution on the substrate surface. Little homopolymerization occurs under these grafting conditions and small amounts of the formed homopolymer can be removed by the washing proper procedure.

To modify PPy and PA membranes by a thin layer of the imprinted polymer, the method of «surface photografting» has been applied. The main reason for this is very high reactivity of the crosslinker ( $N, N^{\prime}$-methylene-bis-acrylamide) and a problem of its homopolymerization in heterogeneous reaction systems. This generally leads to low degrees of the membranes' modification, poor reproducibility and difficulty in recovering copolymer in the noncontaminated form, especially at high grafting yields. The scheme of the «surface photografting» modification of the porous membrane with MIP is presented in the Fig. 1. In this polymerization scheme, the stabilizing effect of highly cross-linked molecularly imprinted polymer in a combination with a flexible, chemically inert and wide pore PPy or PA membrane is utilized.

It is reasonable to assume, that the composition of the monomer mixture determines the ability of the resulting membranes to bind the template selectively 


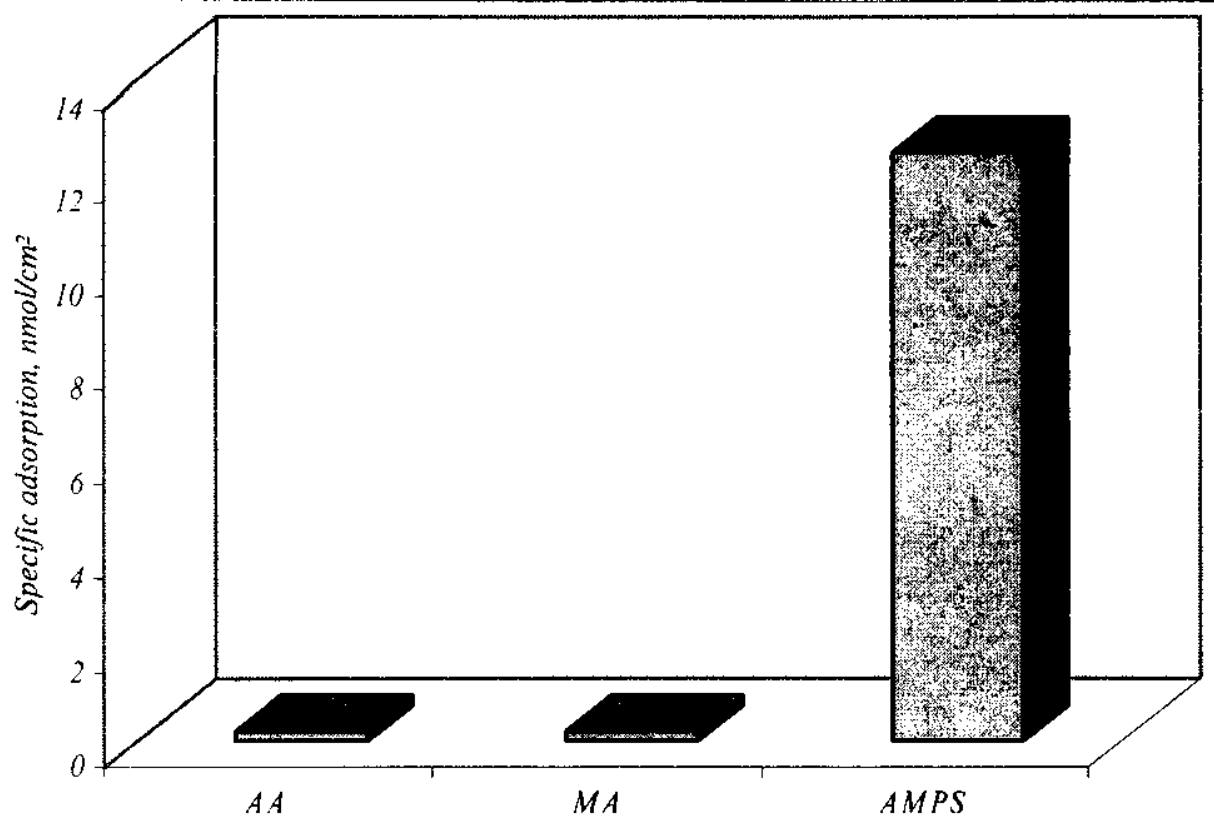

Fig. 2. Influence of the type of the functional monomer on the specific adsorption of terbumeton on the imprinted membranes, $10 \mathrm{ml}$ of $10^{-5} \mathrm{M}$ aqueous solution of terbumeton was used in filtration experiments (see note to the Table) and, thus - the membranes adsorption capacity. Therefore, the influence of the type and concentration of the functional monomer and cross-linker, as well as the template concentration in the monomer mixture, on the ability of the modified membranes to effective adsorption of the template has been investigated.

Influence of a type of the functional monomer on the membranes adsorption capability. Modification of the PPy membranes with imprinted polymers was performed using acrylic, methacrylic or 2-acrylamido2-methyl-1-propane sulphonic acids as functional monomers and $\mathrm{N}, \mathrm{N}^{\prime}$-methylene-bis-acrylamide as a cross-linker. Triazine herbicide terbumeton was used as a model template in the present research. A set of the imprinted and reference membranes with AA, MA or AMPS as functional monomers has been obtained and tested in filtration experiments. AA and MA were demonstrated to be ineffective as functional monomers. The imprinted membranes prepared in the presence of $\mathrm{AA}$ and $\mathrm{MA}$ as functional monomers demonstrated either the same or lower adsorption capability as reference ones. The membranes imprinted with terbumeton and prepared in the presence of AMPS as a functional monomer demonstrated significantly higher adsorption capability than the reference membranes of the same composition (Fig. $2)$. It is assumed that AMPS as a strong acid ( $p K a<$ <1) can protonate terbumeton $(p K a=4.2)$ and an ion-pair complex is formed between the template and AMPS in the initial monomer mixture. For weaker acidic monomers MAA $(p K a=4.65)$ and $\mathrm{AA}(p K a=$ $=4.2$ ) this mechanism is less effective. This has been also confirmed by the investigations of the template- functional monomer complex formation by UV-difference spectroscopy. These data verify that the complex AMPSA-terbumeton is significantly stronger $\left(\mathrm{K}_{\text {dis }}=3.0 \cdot 10^{-5} \pm 0.3 \cdot 10^{-5} \mathrm{M}\right)$ as compared to $\mathrm{AA}$ $\left(\mathrm{K}_{\mathrm{dis}}=2.0 \cdot 10^{-4} \pm 0.3 \cdot 10^{-4} \mathrm{M}\right)$ and MAA $\left(\mathrm{K}_{\mathrm{dis}}=\right.$ $=8.0 \cdot 10^{-5} \pm 1.0 \cdot 10^{-5} \mathrm{M}$ ).

Influence of the cross-linker concentration on photografting and the membranes' adsorption capability. As widely recognized, the effective performance of the imprinted polymer is provided by high degrees of the polymer cross-linking. In this case, the selective cavities can retain their shapes even after extraction of the template. At the same time, a certain degree of the polymer chains' flexibility is important to provide rapid equilibration with the template to be bind. Hence, the influence of a type and amount of the monomer and cross-linker in the monomer mixture used for the membranes modification on both the degree of modification and adsorption capability of the resulting membranes was investigated. The former was explored as a function of the cross-linker concentration ( $\mathrm{N}, \mathrm{N}^{\prime}$-methylene-bis-acrylamide) in the monomer mixture.

The degree of the modification was shown to increase with the increase in the cross-linker concentration in the monomer mixture and to comprise $150-500 \mu \mathrm{g} / \mathrm{cm}^{2}$ of membrane surface (Fig. 3, a). At the same time, the increase in MBAA concentration up to $225 \mathrm{mM}$ caused also the increase in the membranes' adsorption capability (Fig. 3, b). However, further increase in the MBAA caused a decrease in the membranes' adsorption capability. To increase the specific adsorption of the herbicide by MIP 

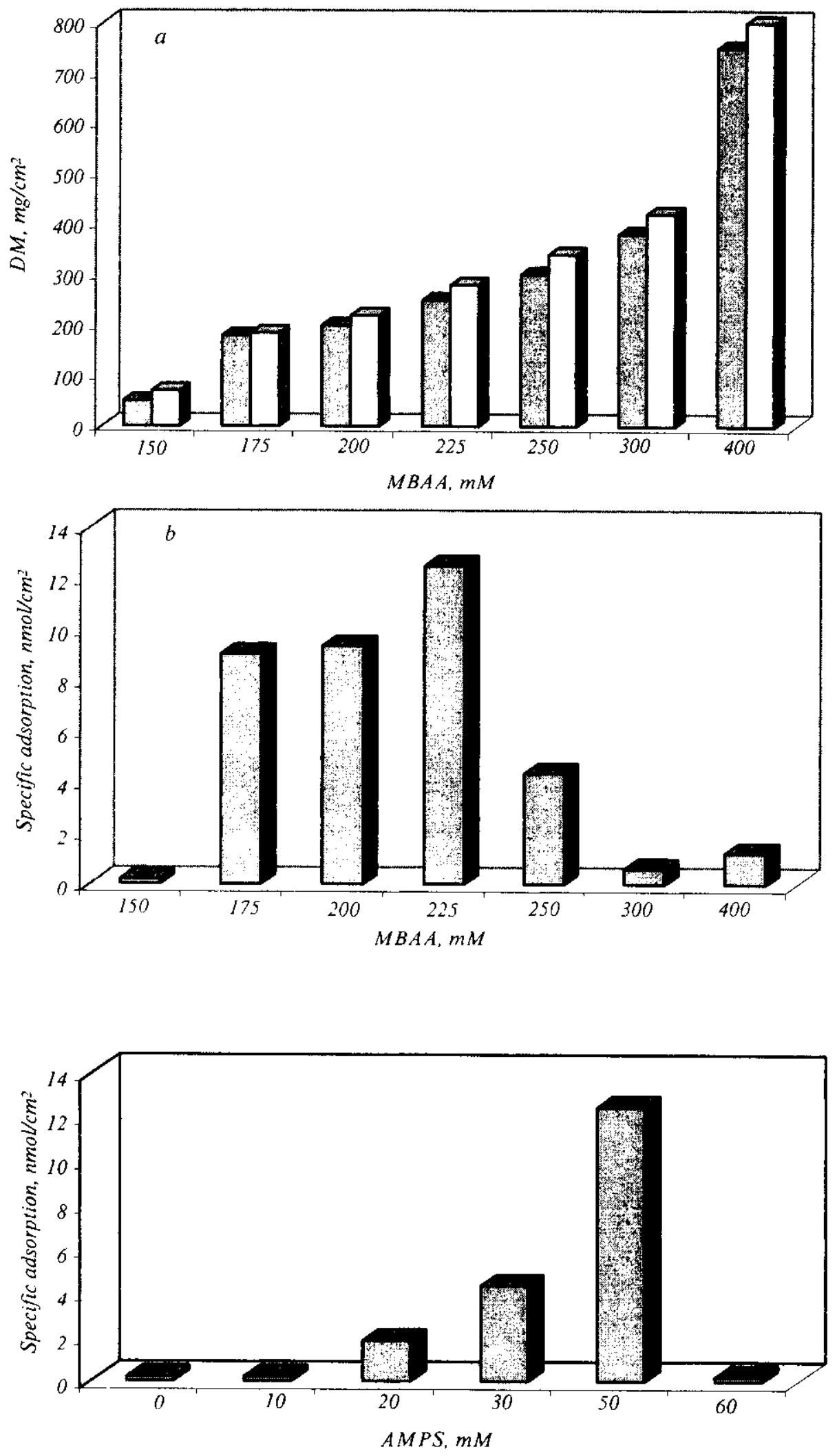

Fig. 3. Deperidence of the degrees of modification of the imprinted (gray bars) and reference (white bars) membranes on the concentration of the cross-linker in the monomer mixlure $(\alpha)$. Dependence of the specific adsurption of lerbumeton on the imprinted membranes on the concentration of the cross-linker in the monomer mixiure (b) (see note to the Table). Template - terbumeton, $10 \mathrm{mM}$, functional monomer - 2-acrylamido-2-methyl-1-propane suiphonic acid, $50 \mathrm{mM}$, cross-linker - N, $N^{\prime}$-methylene-bis-acrylamide, $150-400 \mathrm{mM}$

Fig. 4. Dependence of the specific adsorption of terbumeton on MIP membranes on the concentration of the functional monomer in the monomer mixture (see note wo the Tables. Template - terbumeton, 10 mM. functional monomer 2-acrylamido-2-methyl-1-propane suiphonic acid, $0-80 \mathrm{mM}$, cross-linker $\mathrm{N}, \mathrm{N}$-methylene-bis-acrylamide, $225 \mathrm{mM}$ 


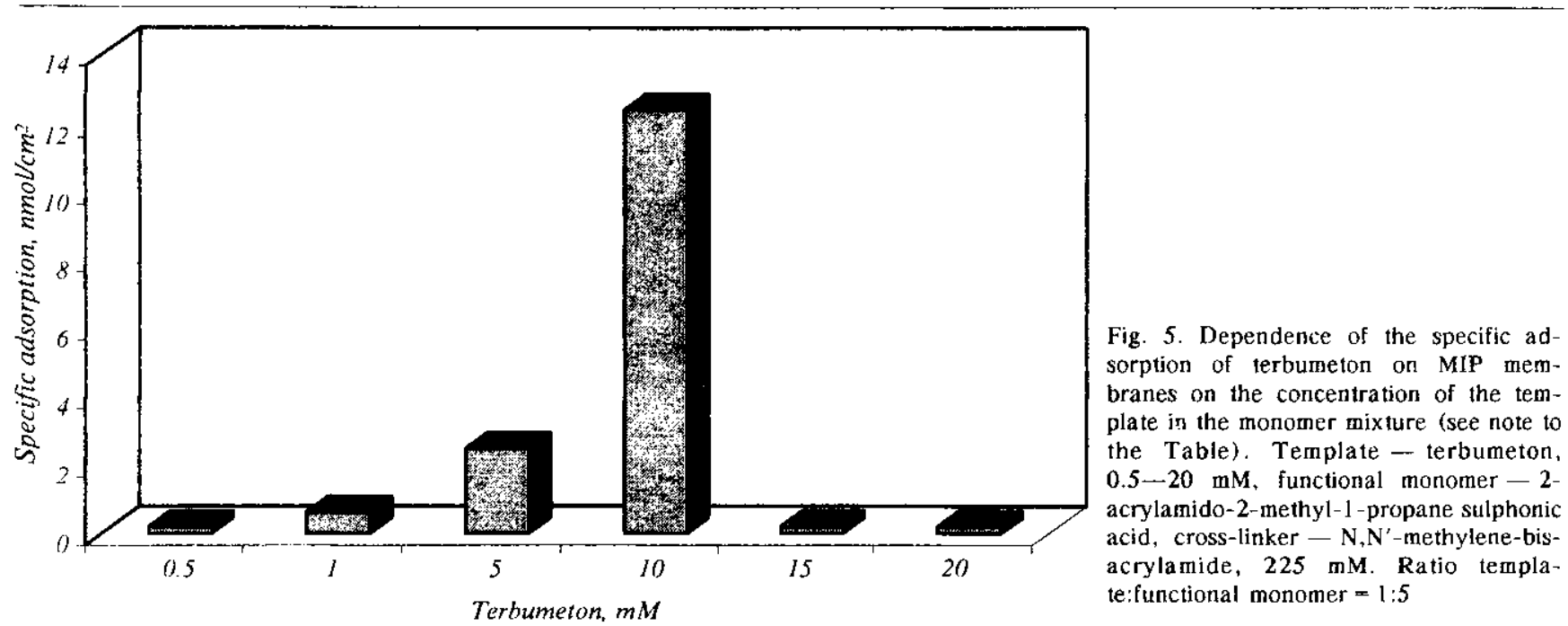

Influence of the support on a degree of modification (DM) and adsorption capability of terbumeton-imprinted (MIP) and reference (Blank) membranes (the monomer mixture, containing $10 \mathrm{mM}$ terbumeton, $10 \mathrm{mM}$ 2-acrylamido-2-methyl-1-propane sulphonic acid and $225 \mathrm{mM}-N, N^{\prime}$-methylene-bis-acrylamide was used for modification of MIP membranes; Blank membranes were prepared with the same monomer composition, but without the template)

\begin{tabular}{|c|c|c|c|c|}
\hline \multirow{2}{*}{ Support } & \multicolumn{2}{|c|}{$\mathrm{PA}, \mu \mathrm{m}$} & \multicolumn{2}{|c|}{ PPy, , al } \\
\hline & MIP & Blank & MIP & Btabk \\
\hline $\mathrm{DM}, \mathrm{mg} / \mathrm{cm}^{2}$ & 443.4 & 510 & 277 & 261 \\
\hline $\begin{array}{l}\text { Specific adsorption, } \\
\text { nmol } / \mathrm{cm}^{2}\end{array}$ & 0 & 0 & 12.5 & 12.5 \\
\hline
\end{tabular}

$\mathrm{N}$ o t e. The value of specific adsorption corresponds to the difference between terbumeton adsorption on a MIP membrane and a reference one, prepared with the same monomer composition but in the absence of the template. The "zero» values of specific adsorption correspond either to the cases of the same adsorption of terbumeton on MIP and reference membranes or to the cases of preferential adsorption of terbumeton on reference membranes.

membranes, i. e. to decrease the level of nonspecific binding, the other cross-linker (trimethylolpropan trimethacrylate) was used. Although the degrees of modification were higher, than in the case of $N, N^{\prime}-$ methylene-bis-acrylamide, the values of specific adsorption were twice lower. This indicates, that high degrees of modification together with excessive degrees of cross-linking are not necessary for the effective performance of MIP membranes. Evidently, at these conditions most of the template molecules are trapped in the excessively cross-linked domains of imprinted polymer and not accessible for the reactions, which results in a decreased amount of the binding sites.

Structure of the binding sites. The AMPS concentration in the monomer mixture was varied to optimize the ratio between the template and a functional monomer used for the membranes' modification. No difference between adsorption capability of imprinted and reference membranes was obtained in the absence of AMPS in the monomer mixture or when its concentration was too low $(10 \mathrm{mM})$. Ob- viously, these ratios yield the imprinted polymers with insufficient extents of the template complexation and, thus, low number of binding sites. Use of AMPS in concentrations of $10-50 \mathrm{mM}$ produced MIP membranes with the improved adsorption capability as compared to reference ones. However, the further increase in AMPS concentration $(60-80 \mathrm{mM})$ leads to formation of the membranes with too high degrees of non-specific binding (Fig. 4). Apparently, this can be explained by an abundance of the polar functional groups distributed randomly throughout the polymer matrix, that results in the reduced selectivity.

Influence of the template concentration. To define the optimal number of binding sites in the resulting membranes, influence of the template concentration on the membrane adsorption capability has been studied. The highest value of specific adsorption was observed at the template concentration of $10 \mathrm{mM}$. Both decrease and increase in the template concentration resulted in either lower or no imprinting effects (Fig. 5). Evidently, a decrease in the template concentration results in the insufficient number of the 


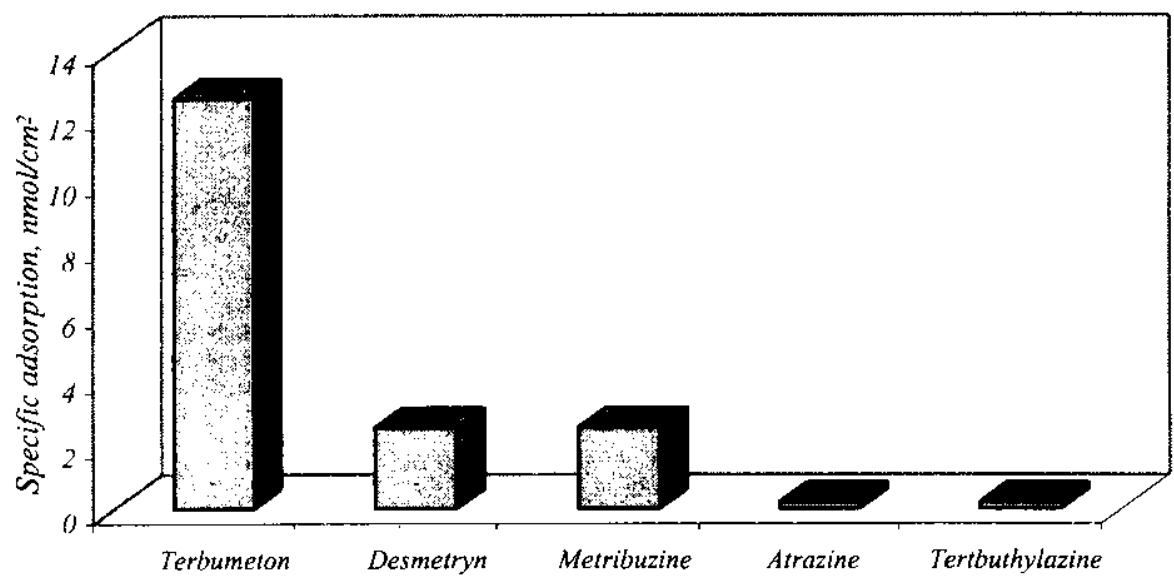

Fig. 6. Selectivity of the terbumeton-imprinted membrane. Template-terbumeton, $10 \mathrm{mM}$, functional monomer - 2-acrylamido-2-methyl-1-propane sulphonic acid, 50 $\mathrm{mM}$, cross-linker - N, $\mathrm{N}^{\prime}$-methylene-bisacrylamide, $225 \mathrm{mM}$ imprinted sites in the polymer. No imprinting effect at $20 \mathrm{mM}$ of terbumeton in the monomer mixture can be explained by its ability to form aggregates in the solution of high concentrations, that results in formation of the increased number of non- and weaklyselective binding sites.

Influence of the support. Importantly, PA membranes modified by the molecularly imprinted polymer layer under optimized conditions, demonstrated higher degree of modification as compared to PPy membranes. However, no improvement in the herbicide binding was achieved. Practically no difference or even preferential herbicide adsorption was observed for reference membrane as compared to the imprinted one (Table). This effect can be related to the increased ability of PA membranes to swell in organic solvents in contrast to PPy membranes. Since there is no swelling of PPy membranes in organic solvents, we can assume that the functionalization takes place in a thin layer on the entire surface of the membrane. In contrast to this, in the case of PA membranes the polymerization reaction takes place in the entire membrane volume, i. e. mainly in the swollen PA matrix. Therefore, the degrees of modification achieved under same conditions are significantly higher for PA than for PPy (Table). However, one can assume that most of the polymer entrapped in PA is not accessible for binding with the template molecules during the fast filtration step. From the other side, swelling of the support changes the three-dimensional configuration of the functional groups participating in the recognition process and may lead to the loss of selectivity. The other explanation can be interaction between amide functionalities in the PA support and the functional monomer, that hinders binding the herbicide by the functional monomer.

Specificity of molecularly imprinted polymer mem- branes and their herbicide-binding efficiency. A series of terbumeton analogs were used to examine the selectivity of the obtained membranes. The capability of the terbumeton-imprinted membranes to bind herbicides of the related chemical structure was tested in filtration experiments. The terbumeton-imprinted membranes were shown to be capable of binding terbumeton analogs much less effectively than terbumeton (Fig. 6). It was demonstrated that the terbumeton-imprinted membranes modified under the optimized conditions were able to recover 95-99\% of terbumeton from its $5 \cdot 10^{-7}-10^{-4} \mathrm{M}$ aqueous solutions (Fig. 7). The adsorption capability of the terbumeton-imprinted membranes was determined in filtration experiments using saturation with $10^{-5} \mathrm{M}$ solution of terbumeton. The value determined was $5 \mu \mathrm{g} / \mathrm{cm}^{2}\left(\sim 22 \mathrm{nM} / \mathrm{cm}^{2}\right)$, which corresponds to approximately $40 \%$ of the theoretical value calculated from the degree of modification and the stochiometry of the template-functional monomer complex. Therefore, they can be successfully used for both water purification and herbicide pre-concentration in environmental analysis.

Conclusions. The new type of composite membranes, having artificial recognition sites for terbumeton, was prepared by «surface photografting» of 2-acrylamido-2-methyl-1-propane sulphonic acid, $\mathrm{N}, \mathrm{N}^{\prime}$ methylene-bis-acrylamide in the presence of terbumeton as a template on a benzophenon-coated polypropylene $0.2 \mu \mathrm{m}$ membranes. The membranes imprinted with terbumeton demonstrated significantly higher adsorption capability to this herbicide than to analogous compounds (terbuthylazine, atrazine, desmetryn, and metribuzine). No affinity for terbumeton was observed for MIP-photografted polyamide membranes, which indicates significant influence of the support on both the imprinting procedure and the process of template recognition. The type and con- 
SERGEYEVA T. A. ET AL

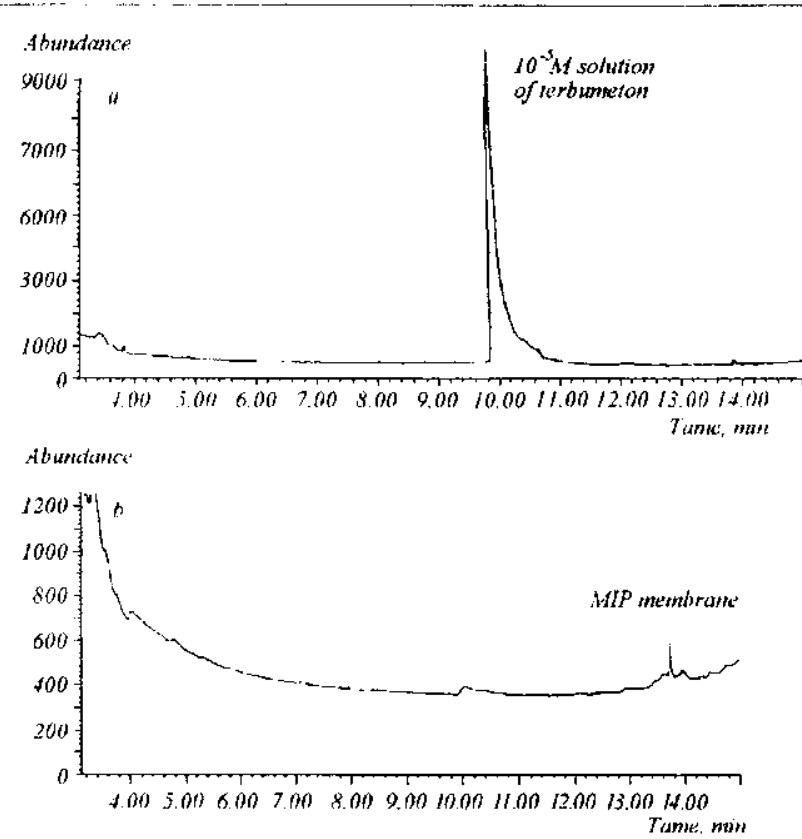

Fig. 7. Chromatograms of the $10^{-5} \mathrm{M}$ terbumeton solution before (a) and after ( $b$ ) filtration through the terbumeton-imprinted (MIP) membrane

centration of the functional monomer as well as the concentration of cross-linker have a crucial influence on the resulting membranes' adsorption capability. High affinity of these membranes to triazine herbicides logether with their simple and inexpensive preparation, provides a good basis for the applications of imprinted polymers in separation, solid-phase extraction, and in a pre-concentration step for the determination of photosynthesis-inhibiting herbicides in water.

Acknowledgements. Financial support from AIF, INTAS (grant YSF-00-25), and National Academy of Sciences of Ukraine is gratefully acknowledged.

\section{T. А. Сересєва, Х. Матуневскі, С. А. Пілещький, У. Нијлер, M. Yutopixm}

Синтез матричних полімерних мембран, селективних до триазинових гербіцидів, методом «поверхневого фотографтингу» Резюме

Синтеззовано новии тип матриєних полімерних мембран иляхом поке'рхн'вої модифікації мікрофільтраційних поліпропіленових нембран, яка полясала в нанесенні на пожерхню тонкого нару матри'ного полімеру, селективного до триазиновоея еербіцияу тербуметону. Матричну полімеризацію

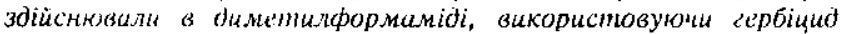
тербуметон як матрицк, 2-акриламідо-2-метил-1-пропансульфонову/метакрилову/акрилову кислоту як функціональнии мономе'р і $N, N^{\prime}$-метилен-бісакриламід як зиивальний агент на поверхні мікрофільтраціиної мембрани, покритої понким инаром фопнтініціатора бензофенону. Екстракція матритних молекул спричинюяала формування в структурі мембрани сай-

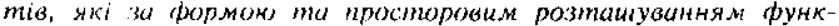

иіональних груп були комилементарними тербуметону. Контрольні мембрани модирікували з використанням подібної суміші мономерів, ич не містила тербуметону. Здатність мембран dо селекмивної абсорбцї̈ тербумстону досліджено в залежності зіј mипу та концентрації функціонального мономера, а також віd концентрації зиивального агента в моно мерній суміші. Показано, що тербуметон-імпринтовані матричні полімерні мембрани характеризуються високою селективністю стосовно пербуметону та здатністю до незначно алсорбцї його струкпурних аналохів - мертбутилазину, атразину, десметрину і метрибузину. Такі властивості синтезо-

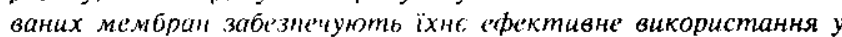

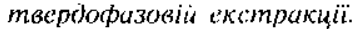

T. А. Сергеева, Х. Матуиевски, С. А. Пилецкий, У. Нидлер, M. Ульбрихm

Синтез матричных пюлимерных мембран, селективньх к триазиновым тербицидам, методом «поверхностного фотографтинга"

Pезкме

Синтезирован новый тип матричньх полимерных мембран метолом позерхностной модификации микрофильтрациониых полипропиленоњьх мембраи, заключакищмея в нанесении на поверхность монкого слоя матричного полимера, селективно го к триазиновому гербицију пербуметону. Матричную поли меризацию проводили в тиметилформамиде с использованием триазинового сербиција тербуметона в каместве матрицы, 2-акриламифо-2-метил-1-пропан-сульфоновой/метакриловой/ акриловоі кислоты как функционального мономера и $N, N^{\prime}-$ метилен-бисакриламида как санывонце'е асента на поверхности макрофиныпрациенной мемборны, покрымой тонким слоем фотоинииианора бензоденона. 'Јкстракиия матричнох моле кул ириволида к формированик в структуре мембраны сайтов, комилементарных "иербуметону по форме и пространственному расположению функииональных срупп. Контрольnве мембраны синле?зоровали с использованием той же моно-

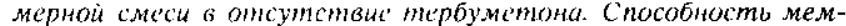
бран $к$ селективнои ансорбины тербуметона исследовали в

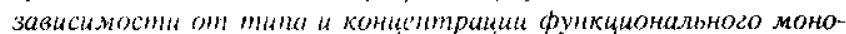
мера, а также концентрации синваницего асента в мономерной смеси. Показано, 'юnо пербуметон-импринтированные матри'нык полимерныс мембраны характеризуются высокой селективностьк к пербуметону и јемонстрируют незначительную абсорбцию его структурних иналогов - тертбутилазина, атразина, десметрина "метрибузина. Такие свойства

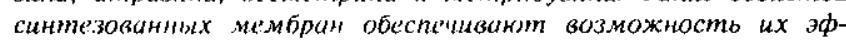
фекпиивного использожания а пверооразной экстракции.

\section{REFERENCES}

1. Kesting $R$. E. Synthetic polymeric membranes. A structural perspective. - New York: John Willey and Sons, 1985.-573 p.

2. Schultz $S$. $G$. Basic principles of membrane transport.Cambridge: Univ. press, 1970.-391 p.

3. Minoura N., Idej K., Rachkov A., Matsuda $K$. Molecularly imprinted polymer membranes with photo-regulated template binding // Chem. Mater.-2003.-15.-P. 255-266.

4. Wulff $G$, Vie'tme'yer $J$, Poll H. $G$. Influence of the nature of the cross-linking agent on the performance of imprinted polymers in racemic resolution // Macromol. Chem.-1987.188. -r. $731-740$.

5. Demen J., Neckers $b$. (. () n the memory of synthesized vinyl polymers for their origins // Tetrahedron let1.-1980.-21.P. $1913 \cdots 1916$ 
6. Ramstrom $O$., Andersson $L . I .$, Mosbach $K$. Recognition sites incorporating both pyridinyl and carboxy functionalities prepared by molecular imprinting // J. Org. Chem.-1993.58. - P. 7562-7564.

7. Ramstrom O., Nicholls I. A., Mosbach K. Synthetic peptide receptor mimics: highly stereoselective recognition in noncovalent molecularly imprinted polymers $/ /$ Tetrahedron Asym. - 1994.-5.-P. 649-656.

8. Siemann $M$., Andersson $L$. I. Mosbach $K$. Selective recognition of the herbicide atrazine by non-covalent molecularly imprinted polymers // J. Agr. Food Chem.-1996.-44.-P. 141-145.

9. Svenson J., Nicholls I. A. On the thermal and chemical stability of molecularly imprinted polymers // Anal. Chim. Acta. $-2001 .-435$, N 1.-P. 19-24.

10. Wulff G., Minarmk $M$. Template-imprinted polymers for HPLC separation of racemates // J. Liq. Chromatogr.1991.-13. N 5.-P. 2987-3000.

11. Valtakis G., Andersson L. I., Muller R., Mosbach K. Drug assay using antibody mimics made by molecular imprinting // Nature. $-1993 .-361 .-P .645-647$

12. Piletsky S. A., Piletskaya E. V., El skaya A. V., Levi R., Yano $K$, Karube 1 . Optical detection system for triazines based on molecularly imprinted polymers // Anal. Lett.-1997.-30.-P. $445-455$

13. Ramstrom $O ., Y_{e} L$, Mosbach $K$. Artificial antibodies to corticosteroids prepared by molecular imprinting // Chem. Biol. - 1996.-3.-P. 471-477.

14. Sergeyeva T. A., Piletsky S. A., Brovko A. A., Slinchenko E. A., Sergeeva L. M., Panasyuk T. L., El skaya A. V. Conductometric sensor for atrazine detection based on molecularly imprinted polymer membranes // Analyst._1999._124.P. $331-334$.

15. Yoshikawa M., Izumi J., Kitao T., Koya S., Sakamoto S. Molecularly imprinted polymeric membranes for optical resolution // J. Membr. Sci. - 1995.-108. - P. $171-175$.

16. Mathew-Krotz $J$., Shea $K$. J. Imprinted polymer membranes for the selective transport of targeted neutral molecules // J. Amer. Chem. Soc.-1996.-118.-P. 8154-8155.

17. Sergeyeva T. A., Piletsky S. A., Piletska E. V., Brovko O. O., Karabanova L. V., Sergeeva L. M., El'skaya A. V., Turner A.
P. F. In situ formation of porous molecularly imprinted polymer membranes // Macromolecules. - 2003. - 36, N 19.P. 7352-7357.

18. Hong J.-M., Anderson P. E., Qian J., Martin C. R. Selectively-permeable ultrathin composite membranes based on molecularly imprinted polymers // Chem. Mater.-1998.-10.P. 1029-1033.

19. Dhal $P$. K., Vidyasankar S., Arnold $F . H$. Surface grafting of functional polymers to macroporous poly(trimethylopropane trimethacrylate) // Chem. Mater.-1995.-7.-P. 154-162.

20. Wang H. Y., Kobayashi T., Fuii N. Surface molecular imprinting on photosensitive dithiocarbamoylpolyacrylonitrile membranes using photograft polymerization // J. Chem. Technol. and Biotechnol. $-1997 .-70, N$ 4.-P. 355-362.

21. Ulbricht $M$. Photo-graft polymer modified microporous membranes with environment-sensitive permeabilities $/ /$ React. Funct. Polym.-1996.-31.-P. 165-177.

22. Tazuke S. Surface photografting. I. Graft polymerization of hydrophilic monomers onto various polymer films // J. Polym. Sci.: Polym. Lett. Ed. -1978.-16.-P. 497-500.

23. Bellobono I. R., Tolusso F., Selli E. Photochemical grafting of acrylated azo dyes onto polymeric surfaces. I. Grafting of 4-(ethyl, N-2-acryloxyethyl) amino, 4'-nitro, azobenzen onto polyamide and polypropylene fibers // J. Appl. Polym. Sci.1981.-26.-P. 619-628.

24. Ang C. H., Garnett J. L., Levot R., Long M. A. Radiation and UV grafting of monomers to polyolefins and cellulose acetate. Significance of these studies in reagent insolubilization reactions // J. Macromol. Sci. Chem. - 1 982.-A17.-P. 87-98.

25. Pashova V. S., Georgiev G. S., Dakov V. A. Photoinitiated graft copolymerization of glicydyl methacrylate and 2-hydroxyethyl methacrylate onto polyacrylonitrile and application of the synthesized graft copolymers in penicillin-amidase immobilization // J. Appl. Polym. Sci.-1 1994.-51.-P. 807-813.

26. Ramby B., Guo F. Z. «Surface photografting». New applications to synthetic fibers // Polym. Avd. Technol.-1994.-5.P. $829-836$.

удК $544.725+544.722 .21+577.21$ Надійшла до редакції 22.12.03 